\title{
The revival of solidarity in disasters- a theoretical approach
}

\author{
Ulrike Sasse-Zeltner (ulrike.sasse-zeltner@ovgu.de) \\ Otto-von-Guericke-Universität Magdeburg, Germany
}

During the COVID-19 pandemic, the term solidarity has been on everyone's lips. We are also witnessing changes at record speed in the institutionalized solidarity provided by the welfare state (e.g., temporary emergency allowances or special regulations in tenancy law) along with the emergence of new forms of solidary local communal relationships. All this has triggered a host of empirical research on practices of solidarity all over the world. What we lack, however, is a theoretically based explanation for the overarching question of why this crisis is associated with a rise in solidarity. The article aims to address this research gap by supplementing solidarity theories in the context of social policy with a disaster-research perspective. To this end, the current coronavirus pandemic is understood not only as a crisis but as a global catastrophe consisting of different local disasters. To understand these processes, the paper revisits various approaches from disaster research to derive theoretical propositions about the current pandemic and to provide a deeper understanding of the emergence of solidarity in disasters. Specifically, I adapt Lars Clausen's macrosociological model of disaster figurations (PERDUE model) to solidarity research. This model enables an interdisciplinary analysis of the changes in solidarity for different national societies and from a European comparative perspective. The objective of this theory paper is to collect preliminary considerations that would need to be incorporated into an adequate analytical model of solidarity practices in the current COVID-19 pandemic.

Keywords: Solidarity, disaster, institution, sociological theory

\section{Introduction}

The current COVID-19 pandemic has not only revived solidarity practices but also long familiar theoretical questions. There seems to be a "gold rush" in the field of disaster research (Alexander, 2020) and even in such niche disciplines as medical history. Suddenly, researchers from these fields are very much in demand as interview guests (Borck, 2020). Questions about how people behaved in past pandemics and whether their behaviour in such states of emergency can be predicted are becoming relevant not only in TV shows but even more so in the political arena. Especially, when an ongoing catastrophe calls for countermeasures that depend on the social behaviour of people, the question of why people in crises behave in solidarity is perhaps even more important than the empirical description of increased solidarity practices. This is especially true when the term solidarity is used to describe a wide range of practices at both the level of civil society and government as was the case around the world last year. Across countries, for example, digitally disseminated expressions of solidarity under various hashtags and applause for the heroines and heroes of the pandemic characterized the initial phase in the spring of 2020. Social 
distancing and staying home were seen as acts of solidarity not only with at-risk groups but also with systemically important individuals who went on to work for everyone else. In contrast, what is most striking in the current debate is the absence of substantial acts of solidarity by the state with these applauded groups of individuals and professions. Financial compensation for the extraordinary burdens or other structural improvements especially in the overburdened health-care systems have been very modest at best and oriented toward the short term compared to the huge rescue packages for the economy. In principle, however, the institutional solidarity practices that could be observed outshine any of the responses to similar situations before, including those to the 2008 financial crisis. Both the speed, the financial amount and the depth of state intervention are unprecedented in recent times and have been readily justified on grounds of solidarity.

While much empirical research has been launched to investigate current events throughout Europe, theoretical considerations to answer the question of why we are observing a revival of solidarity and what follows from this have been rather rare so far. If social trends really do show up more clearly under the burning glass of crises and catastrophes (for a critical view of this see Stehrenberger, 2020), as can be heard everywhere, then we should be able to find theoretically profound reasons for this in the body of almost one hundred years of disaster research. If one takes the time to sort through the existent research on solidarity and social behaviour in times of crisis, it quickly becomes clear that the question of population behaviour in crises and disasters has been a classic question since the beginnings of disaster research and that we may not have to reinvent the wheel to understand behaviour in the current pandemic. This was shown only recently by Daniel Lorenz and Cordula Dittmer in their article on prosocial behaviour in disasters, in which they discuss the phenomena of "utopian moments" in affected communities (Lorenz \& Dittmer, 2020), demonstrating the chances for future research on this topic.

The following article presents theoretical considerations of disaster research and adapts them to solidarity research. The aim is to provide a collection of preliminary theoretical considerations that would need to be incorporated into a model for analyzing solidarity practices in the current COVID-19 pandemic.

This theory paper is structured as follows. I demonstrate that the institutional framework of the current COVID-19 pandemic itself suggests that it is useful to adopt a differentiated disaster sociological perspective and thereby distinguish between the categories of disaster and catastrophe. This will be deepened in the second section. The third section is devoted to making the general findings of disaster research on the analytical categories of time and on expected prosocial behaviour in disasters fruitful for the analysis of disasterspecific practices of solidarity. The fourth part addresses solidarity in pandemics and discusses some theoretical explanations from previous disaster research on private disasterspecific solidarity from below before I reflect on the prerequisites for a systematic analysis of the currently extremely rapidly changing state of institutional solidarity. Concluding that such an analytical model would have to allow for both exogenous and endogenous causes of disaster, I introduce Lars Clausen's macrosociological process model called 'PERDUE'. The fifth part briefly demonstrates its potential as a basis for a detailed case study by referring to selected German examples for the purpose of illustration. I close by outlining an interdisciplinary research perspective for a systematic analysis of pandemic-specific solidarity.

At first glance, the question of the structural conditions of the COVID-19 pandemic seems to be easy to answer given that the WHO has already declared an international disaster on 30 January 2020 and speaks of a public-health emergency of international concern. It is the highest alert level on its scale and explicitly adopts a global perspective. Since $11 \mathrm{March}$ 2020, COVID-19 is officially a global pandemic (WHO, 2020). The EU Civil Protection 
Mechanism has also been activated at the European level, so that the EU is not only officially experiencing a crisis but also legally in a state of disaster (DG ECHO, 2020).

At the national level, however, the responses of the member states vary considerably. The consequential damage of the pandemic has already been visible for months at various levels, and many governments have declared a legal state of emergency, enabling them to take far-reaching political measures (for a currently available overview see: Wikipedia, 2020). In France, for example, Macron "declared war" (Erlanger, 2020) on the virus early on and has now extended the state of emergency until February 2021. After a pause during the summer that was ended by increasing infection numbers, Spain is now also in a state of emergency again without a completely new disaster having occurred (DW, 2020). Due to the federal structure of the Federal Republic of Germany, only the federal states and regional authorities can declare a state of emergency, which only a few did (e.g., the state of Bavaria or the city of Halle). The federal government in Germany is responsible for civil protection only in the event of war and can provide funds for the federal states only in the event of a disaster through disaster relief but is not itself authorized to issue directives (ZSKG). At the local level, the region of Bergamo in northern Italy or New York in the USA are examples of special cases in terms of how the COVID-19 pandemic was interpreted as the respective health-care systems were rapidly overburdened early on. Here, the pandemic quickly took the shape of a local disaster with all the consequences that this entails such as the deployment of civil-protection or military forces and the request for federal assistance (Riegert, 2021; Pitzke, 2020; Wikipedia 2020).

These examples show very clearly that the COVID-19 pandemic is categorized differently depending on its location and for this reason alone cannot simply be investigated using a standardized model of disasters. Any detailed case study on the solidarity practices during COVID-19 must consider these specific local conditions.

Throughout the history of mankind, much has been written about past epidemics. Specific to the current pandemic, is not the disease but the global political reactions to it. COVID19 is not even particularly mortal compared to the plague or Ebola, but since the infection can occur with no or hardly any noticeable symptoms, its spread is very difficult to predict. Because of this potential for uncontrolled mass spread, even small percentages of severe and lethal cases can become crucial for maintaining the capacities of health-care systems. The fight is therefore being fought against excessively high predicted figures and rather rarely against the visible effects of the virus itself. The political responses and reactions to COVID-19 worldwide are largely preventive precautionary policies designed to prevent a collapse of health-care systems. They include several measures that can be understood implicitly or explicitly as institutional solidarity. Since the institutionalization of solidarity instruments usually proceeds in an incremental fashion and has historically developed along culturally different paths over exceptionally long periods of time (Esping-Andersen, 1990; Kaufmann, 2013), there is a need to explain how this disaster-specific, very rapid institutional solidarity change took place. Moreover, the solidarity practices from below that have been unleashed during this pandemic are also extraordinary, even for disaster research, because "in the current pandemic crisis, we are witnessing this flowering of social solidarity and creativity on a heretofore almost unimaginable scale" (Tierney, 2020, 4). This leads to the following question. What can we conclude about the COVID-19 pandemic from previous social-science disaster research? To address this question, however, we first need to clarify another one. What is a pandemic seen from a disaster-research perspective? Should it be considered a crisis, a disaster or a catastrophe? The next section will deal with these questions in detail. 


\section{Pandemics in disaster research - crisis, catastrophe or disaster?}

The last truly global pandemic - the Spanish flu from 1918-1920-dates back more than one hundred years ago to a time when there was no systematic disaster research with findings on pandemics that we could draw on today for COVID-19. However, there is a vast body of research on social factors in other collective crises (Geenen, 2003) that can be employed to understand the social dynamics of the current pandemic. Even if the scale of this pandemic is entirely new, we can revisit insights from nearly one hundred years of disaster research. Many findings are controversial, but the consensus is that "the knowledge base of social science disaster research is relevant to the current coronavirus crisis" (Tierney, 2020, 2).

Samuel Prince is considered a pioneer of disaster research and one of the first to take a closer look at communities in a case of emergency (Scanlon, 1988). He based his disaster research on a study of the Halifax explosion and, as early as 1920, called it Catastrophe and social change. A few years later, in 1932, Lowell Juillard Carr was "the first in the field to try to understand disasters in terms of social action" (Dombrowsky, 1998, 18). In his research, he concentrated on 'cultural protections' and not just on physical impacts (Carr 1932). Since World War II and the US National Opinion Research Center (NORC) studies at the latest, which examined population behaviour in the event of war, research on social behaviour in disasters and not physical destruction has been the core area of the discipline (Dombrowsky, 2008, 53).

Thus, today's disaster research has long agreed that there are no purely natural hazards but socially constructed disasters and catastrophes (Quarantelli \& Dynes, 1977; Clausen et al., 2003; Voss, 2006; Dombrowsky, 2010; Oliver-Smith \& Hoffman, 2020). Yet how the term disaster is to be defined and how it differs from collective crises (Geenen, 2003, 12ff.) and catastrophes is still disputed within the discipline (Quarantelli, 1998; Perry \& Quarantelli, 2005; Clausen et. al., 2003; Oliver-Smith, 2020; Montano \& Savitt, 2020).

A widespread pragmatic distinction between "everyday emergencies", "disasters" and "catastrophes" (Geenen, 2003,13) was made, especially in the English-speaking world, by Enrico Quarantelli:

"Just as there are major differences between behaviours in everyday emergencies and community disasters, there are also differences between disasters and catastrophes. For example in the typical disaster, the homeless seek shelter with local friends and relatives; in catastrophes since most everyone is homeless that cannot occur. So, the facilities and operational bases of almost all emergency organizations are often directly hit in a catastrophe; this seldom occurs in a disaster. Different planning for the managing of a catastrophic occasion than of a disaster is required. Of course, what would be catastrophic for a small town might be only disastrous for a metropolitan area." (Quarantelli cited in Geenen, 2003, 13)

According to Geenen, Quarantelli draws her classical distinction between "disaster" and "catastrophe" along the lines of the magnitude of events, the dimensions of affectedness and the restriction of the ability to act. For events to qualify as a catastrophe in this view, the following four requirements must be met:

"1. The entire community is affected, so that almost everyone is in a similar situation (without shelter); 2. most of the facilities and operational bases of the emergency response and emergency organizations are themselves affected; 3. local authorities are also unable to assume their usual working roles, not only in the course of the SAR (search and rescue) phase but also during recovery and reconstruction; 4. most of the community's daily functions are simultaneously and sharply disrupted." (Geenen, 2003, 13, own translation) 
In this sense, the COVID-19 pandemic is neither a typical disaster nor a catastrophe. Instead, it combines characteristics of both types. The global scope and the extensive involvement of all actors and emergency organizations speak for a catastrophe. While the temporally and spatially differentiated spread of the virus creates many local disasters.

This conflicted question of the categorization of the COVID-19 pandemic and its consequences has recently been discussed in detail by Samantha Montano and Amanda Savitt (2020). In their article, they use the traditional differentiation between emergencies, disasters and catastrophes as different types of hazards and discuss why the pandemic does not really fit any one of these categories. They point out what kinds of problems are involved in handling this event in general and in emergency management and disaster response in particular. Moreover, following Quarantelli, they stress that for the discipline "this is not just a theoretical exercise, but a practical one" (Montano \& Savitt, 2020, 4). As the focus here is on solidarity, I will not go into these details further but want to follow the authors' line of reasoning. They conclude: "Although the ongoing pandemic does not fit neatly into a category, as discussed above, it is most appropriate to view it through the lens of catastrophe, rather than a more localized and less impactful disaster" (ibid.). In this vein, I will use the term 'catastrophe' in referring to the global pandemic.

This linguistic distinction also reveals a difference in the development of what in German sociology has been termed Katastrophensoziologie and the American disaster studies. The former is characterized by the theoretical macrosociological perspective of the founder of German disaster research, Lars Clausen, while the latter is particularly characterized by numerous state-financed practice-oriented American case studies of the 1950's (Dombrowsky, 1995, 2008, 53ff.; Clausen \& Dombrowsky, 1983). Since both of these lines of research would designate a global pandemic a catastrophe, I will use the term disaster in the context of the current collective crisis only for locally limited outbreaks and stick to the term catastrophe when referring to the overall phenomenon. I will specify this usage in more detail in the last section on the basis of Lars Clausen's PERDUE model.

\section{General findings of disaster research}

In the daily practice of disaster management, concepts have long since been in place that regard disasters as exogenous events occurring more or less unpredictably and therefore requiring professional preparation. In the same way that one would think about controlling or containing the spatial or temporal extension of the disaster, the anticipated behaviour of the affected people had to be considered. For practitioners, population in this context has long been just a single factor among others. Therefore, models were particularly popular in empirical case studies that divide these events into temporal phases of a pre-impact and post-impact event and into geographical areas (often in circles) around an impact area. Researchers have conducted numerous case studies and developed various disaster models to predict population behaviour in certain scenarios such as (nuclear) bomb attacks, earthquakes, tsunamis, wildfires and the like in order to establish solid theoretical foundations and explanations for civil protection and disaster control, ultimately in the hope of devising a universal disaster scheme. Even though this attempt to classify these models for the American Federal Emergency Management Agency (FEMA) was abandoned in the 1970s because of the excessive complexity and diversity of the individual cases (Dombrowsky, 1983, 28), this body of work still provides a general overview of the current situation and some useful points of reference for deriving insights on solidarity practices.

\subsection{Typologies}

Russell Dynes (1976) tried to classify catastrophes in relation to their "causes", "frequency of occurrence", "predictability" and "controllability". He developed a typology of disasters in which he expected the degree of destruction and reactions to vary from type to type 
depending on their respective characteristics in terms of "rapidity", "early warning time", "duration of effect" and "spatial extent" (quoted in Dombrowsky, 1983, 26-27; own translation). In this typology, the current pandemic would fall into type 4 of a long-lasting cause with an increasing threat, as this characterizes epidemics or droughts in general. By contrast, we would expect different social behaviour in type 1 disasters, for example, which are characterized by a single cause with a limited duration such as tsunamis or explosions. Even if this typology itself does not make precise statements on solidarity in pandemics, the temporal duration of the threat is of great importance for any considerations on solidarity in the current situation. A first aspect that we need to think about in a systematic analysis of solidarity in crisis situations should therefore be how the temporal persistence of a threat is likely to have an impact on solidarity practices. Taking into account this temporal aspect, it is likely that different phases of solidarity practices may occur that vary widely in expression and intensity. And it can be expected that some practices are only short-term phenomena. On the basis of these considerations the paper will discuss successive phases of different solidarity practices. In considering these phases, we should bear in mind that initial empirical observations may not extend throughout the pandemic.

Besides the temporal aspect during a disaster, its long-term development is also interesting. According to Michael Barkun's (1977) cross-epochal categorization of disasters in history, the quality of disasters has changed in terms of both their causes and their temporal and spatial boundaries. He distinguishes between "three disaster modalities between $\mathrm{c}$. 1750 and the present" (Barkun, 1977, 219) and links this to changes in these six dimensions:

"Pervasiveness versus boundedness; transitoriness versus chronicity (i.e. short- $v$. long-term); randomness versus expectability; natural causes versus artificial causes; perceived solvability versus perceived insolvability; and substantive content (whether political, economic, social etc.)." (ibid.)

Barkun $(1977,220)$ believes that, in the wake of the industrial revolution, the once prevalent "homeostatic disasters", which automatically return to an equilibrium, have been displaced by a new type of "metastatic disasters", which he describes as an "artificial catastrophe caused by human behavior and whose unclear spatial and temporal boundaries make [the] return to equilibrium problematic" (ibid.). All natural disasters are instances of the homeostatic type, whereas "explosions, local economic fluctuations, and most conventional warfare" (ibid.) are examples of the metastatic type. The current pandemic, however, falls within a third, new type that emerged in the 20th century and which Barkun calls "hyperstatic disasters". He defines this type of disaster as an "artificial catastrophe intensified to the point of completely obliterating discernible spatial and temporal boundaries, through global extension and system-destroying properties" (ibid).

Unlike past epidemics in the history of mankind, the COVID-19 pandemic is no longer a homeostatic disaster. Compared to 'natural' epidemics, which were geographically relatively limited by long travel times and low population density, the pandemic will not end on its own and is driven by human activity. The new report of the Intergovernmental Science-Policy Platform on Biodiversity and Ecosystem Services (IPBES) explicitly warns of a coming "era of pandemics" (IPBES, 2020) with up to 827,000 zoonoses that could have the ability to infect people. To prevent them, the platform recommends that the world's governments take concrete action to address those same human activities that are driving climate change and biodiversity loss. Climate change, human civilization and globalization are causes of the growing potential danger of pandemics (IPBES, 2020). With this in mind, I interpret the current COVID-19 pandemic, which has already spread globally and has consequences for all social systems, as being a partly artificial catastrophe in Barkun's sense. According to his definition, it qualifies as a hyperstatic catastrophe. It is not expected to 
disappear by itself, rather the whole world is waiting for artificial vaccines to provide a technical solution to contain the disease. In the context of the debate on climate change and the Anthropocene, awareness of the long-term effects of pandemics is increasing and a kind of public awareness of the growing risks of similar viruses is taking place. It can be assumed that this particular type of catastrophe will shape the social behaviour of populations in the long term and cast new doubts on the controllability of nature.

This impact on behaviour gives reason to harbour a second expectation with respect to the social effects of the current pandemic. The spatial and temporal dissolution of boundaries has entailed changes in the qualities of disasters over the course of history. This applies to pandemics as well. Because the COVID-19 pandemic will not end automatically, some of the social changes that it will have brought about can be assumed to be long-term and here to stay. Among those changes is a growing awareness of vulnerability of societies to highly infectious diseases. This sensitization to new risks can lead to an increased search for either technical or non-technical solutions. Either way, the COVID-19 pandemic makes it clear that success in the domination of nature-in this case in the form of controlling or eradicating a highly infectious disease by means of vaccines and other technical remedies - cannot be taken for granted. The already tarnished narrative of the control of nature and technical solutions to all problems continues to lose plausibility and appeal, a development which may have consequences for non-technical solutions. As the plausibility of the technical control narrative erodes, it is likely that alternative non-technical solutions such as cooperative disease-related social solidarity practices might become more attractive.

\subsection{Disaster myths and prosocial behaviour}

Apart from the disaster typologies mentioned above, the results of the numerous case studies on disasters are especially interesting for an analysis of solidarity practices in the current situation. For decades it has been considered a proven fact that most disaster situations involve no panic and looting but rather prosocial behaviour and increasing solidarity and willingness to cooperate (Quarantelli \& Dynes, 1977, 43ff.; Hoffman, 2020a, 144ff., 2020b; Geenen, 2010, 75-77; Quarantelli, 2003; Holenstein \& Köng, 2014; Tierney, 2020, 2). Many different studies have shown that the reports of panic, looting and chaos are persistent disaster myths kept alive by the mass media (Quarantelli \& Dynes, 1977; Geenen, 2003, 14; Prisching, 2005, 171; Lorenz 2010, 73). From the perspective of disaster research, the increased willingness to cooperate and the phenomena of solidarity are thus less a remarkable exception than the norm when it comes to behaviour in the event of disaster.

However, these studies have largely been conducted in Western societies (Geenen, 2010; Holenstein \& Köng, 2014), mostly in the USA, so that we cannot know for sure whether such an increase in solidarity in the event of disaster can be generalized to other settings as well. The basic idea informing these studies is that the stability and condition of a society before the occurrence of a disaster highly influences social behaviour and norms in a subsequent disastrous event. The given state of a society is therefore decisive for the moral values and norms applied in an emergency. On a cultural level, it can be assumed that people in rich societies with a political high stability and a strong welfare state in principle place more trust in the authorities (Geenen, 2010, 121ff; Prisching, 2005, 59f.; Prainsack, $2020,130)$. The classic ideas of social unrest and looting in disasters are no more than empirically untenable disaster myths pushed mainly by journalists. They were the ones to be caught off guard by the massive worldwide prosocial behaviour in the beginning of the current pandemic. Even though decades of empirical research have shown that it should come as no surprise to disaster researchers that COVID-19 has given rise to solidarity 
practices, it still is not well understood why this increase in solidarity occurs in the event of a crisis. In the following, I will put some theoretical explanations up for discussion.

\section{Solidarity in pandemics}

Ever since Emile Durkheim (1964 [1893]) distinguished between mechanical and organic solidarity, the concepts of solidarity have been contested in the social sciences. Until today there are many different definitions and scientific approaches (Bayertz, 1998; Prisching, 2003; Hondrich \& Koch-Arzberger, 1992). Solidarity is usually conceived differently at the micro, meso and macro levels. This does not mean, however, that these concepts must be mutually exclusive. In a constructivist understanding, solidarity is seen as a dynamic process in which the conditions of the formation and construction of affiliations can become the focus of analysis (Börner, 2018, 27ff.). In this perspective initial solidarity practices on a micro level can be institutionalized over time, even to the point of a state structure such as the welfare state. In this paper, institutionalization is also understood as an ongoing process involving smooth transitions from the micro to the macro level. Accordingly, an analysis can range from solidarity practices at the private micro level to the (supra-)state macro level. Groups and organizations on the meso level can of course be private as well as public or governmental. Many intermediate levels are also possible.

Regardless of the respective interpretation of solidarity, the phenomenon of solidarity is naturally linked to crises, also in social-policy and welfare-state research, since both private and state solidarity are in demand in moments of need. Solidarity is called for when something goes wrong. Solidarity practices are always practices of support. The difference between everyday forms of solidarity and solidarity in disasters is that the former typically comes with much less extreme time pressure than the latter. Individual actors and civilsociety groups can spontaneously emerge on the private level when a problem is pressing, but one can also plan long-term solidarity structures and networks. At the state level, by contrast, the institutionalization of solidarity takes a long time, and institutionalized practices have usually grown historically over long periods (Dallinger, 2009; Börner, 2013; Prainsack, 2020).

The assertion made here is that the differing temporal structure in disasters has consequences for disaster-specific solidarity at the micro level of private individual actors as well as at an institutional meso level and the macro level of the state. Furthermore, the current disaster-specific solidarity as opposed to solidarity in 'normal times' is influenced by some special characteristics of a pandemic as a specific type of disaster. Besides physical factors, like the risk of contagion, there are many aspects of an institutional framework that need to be taken into consideration. For example, the aforementioned legal provisions in pandemics implemented as local, regional, national and international institutionalized law are relevant to the possible practices of solidarity. The institutional framework and its condition thus enables or prevents solidarity practices on all levels. Sections 4.1 and 4.2 discuss these characteristics and their implications for private and institutional solidarity practices.

\subsection{Private solidarity: Individual and group solidarity at the micro level}

Wolf Dombrowsky dealt with the problem of solidarity both empirically and theoretically in 1981 on the occasion of a snow disaster of unusual magnitude for northern Germany. Drawing on Ferdinand Tönnies (1887), Dombrowsky argued that disaster-specific solidarity must be conceived as deliberate act of Vergemeinschaftung by individuals to prevent the socially problematic consequences of disasters (Dombrowsky, 1981, 27). He explicitly sees no place in disasters for the principle of anonymous Vergesellschaftung, which underpins state or institutional forms of solidarity and works behind people's backs (ibid.). This kind of solidarity as part of an institutional order is just as much at risk of collapse in the event of a disaster as are other important social functions. This line of theorizing thus expects 
little power at the meso and macro level to explain solidarity phenomena. In this perspective, individual and group solidarity at the micro level increase as a result of processes of Vergemeinschaftung in the pandemic. When institutional order and welfare functions collapse, institutional solidarity at the meso and macro level, which are based on processes of Vergesellschaftung and a functional division of labour, also breaks down. This could also occur, for example, if the worst-case scenario were not a direct collapse of the state but if the local welfare authorities, such as the job centres for the unemployed, were no longer able to function due to a pandemic. Functionality is understood here as a continuum between the poles of unrestricted readiness for action and total collapse.

Dombrowsky differentiates even further drawing on Durkheim's distinction between "mechanical" and "organic solidarity" (Dombrowsky, 1981, 28). If newly emerging individual solidarity practices are a reaction to the consequences of a disaster, they no longer replace everyday routines but can be understood as special programmes of social action to accommodate extraordinary circumstances. An example in the pandemic would be neighbourhood cooperation in the form of self-organized childcare or home schooling. These spontaneously emerging solidarity practices respond to dysfunction of professional childcare and education, which is otherwise organized via a division of labour. On the micro level, they can be conceived of as mechanical solidarity based on local communities that compensate for the loss of organic solidarity.

The switch to new routines does not apply equally to all members of society. Not all everyday routines break down; for some, they only change into disaster routines. This is especially true for members of civil protection, fire departments and other institutions, who in their professional role always work with special programmes of social action to address crisis situations. Yet a pandemic is not an everyday scenario for these professional helpers either, so that they too may be restricted and affected in their functionality. In times of a pandemic, for example, the solidarity of a volunteer fire department in a small village may well break down for a lack of infection protection. Some professional disaster relief workers, however, may routinely be offered special training courses, say by the Red Cross, for dealing with highly infectious diseases, in which medical and technical personnel, for example, learn how to handle and work with full-body protective equipment. Workers trained in this way, who may have rehearsed these techniques for relief operations such as Ebola epidemics abroad, can of course also apply these special programmes of social action in a COVID-19 pandemic at home. We can therefore conclude that increased solidarity practices depend on the respective group affiliation and the competencies of the actors. Furthermore, the collapse of institutional solidarity at the meso and macro levels is highly dependent on the disaster scenario and should therefore never be viewed in a generalized but rather in a differentiated manner.

Ralph Turner (1967) offered a similar theoretical perspective when he reinterpreted Durkheim's distinction between mechanical and organic solidarity with regard to group reactions to disasters:

"Apparently, when the division of labor which supports organic solidarity breaks down, there is often a resurgence of mechanical solidarity, based upon the vital sense of shared sentiment among the victims and other persons directly or indirectly involved in the disaster." (Turner, 1967, 62)

In contrast to Dombrowsky's reading, Turner emphasizes the differences between in- and out-group distinctions in mechanical solidarity. As early as 1967, he described the phenomenon of an "intolerance of outsiders" towards disaster-relief workers and assumed that "the discovery of heightened solidarity within crucial group boundaries [takes place], and especially among persons believed to share the common sentiments of disaster victims" (ibid, 61). Thus, although disasters can lead people to overcome differences and 
conflict, the prerequisite for this is a shared experience of the situation and mutual recognition as victims or at least as being affected. In this sense, the resulting solidarity is exclusive. Being affected and recognized as a jointly affected group is a prerequisite for the increase in exclusive group solidarity in disaster.

Turner's considerations, however, go far beyond mechanical solidarity. His focus is on the relationship between mechanical and organic solidarity. With this focus, he contradicts Durkheim's evolutionary model and instead posits mechanical solidarity as a functional "precondition to the activation of an organized division of labor" (ibid, 62). On the basis of the assumption that mechanical solidarity must be present as a necessary "effective substratum" for organic solidarity, Turner is concerned with the visibility of solidarity in a society. He concludes that it is sufficient if organic solidarity is implicitly given and "merely to the degree to which a common consciousness has come to be taken for granted" (ibid, 62). Building on this, he sees the necessity of the "enactment of solidarity" in crises and disasters in which organic solidarity and the division of labour are endangered or when this acceptance of a common set of standards no longer exists (ibid, 63). In this vein, the highly visible expressions of solidarity in public discourse during the current pandemic can be read as social acts of reassurance that basic mechanical solidarity still exists. At the same time, the permanent invocation of and appeal to solidarity during the previous year are a sign of the fragility of organic solidarity. The discussion about the systemic relevance of certain professions and the associated expressions of solidarity with medical personnel that have accompanied the pandemic is a vivid illustration of this. If one's own role in the division of labour is not considered to be systemically relevant, being reassured, via a joint expression of underlying mechanical solidarity, that one belongs to the group of those affected appears to be particularly comforting.

In summary, in this theoretical perspective, declarations of solidarity and the public display of solidarity are a necessary reaction to the threat to organic solidarity in a society based on the division of labour. They have a stabilizing and reaffirming function, especially in pandemics that lead to severe isolation.

In her literature study on population behaviour in multicultural societies, Elke M. Geenen (2010) proposes a socio-psychological explanation of the rise of solidarity practices on an individual level to which many theoretical approaches to solidarity refer. Drawing on Hugh Miller's anthropological group theory (1964), which assumes that people in groups had evolutionary advantages through "insulation from selective pressures" (quoted in Claessens, 2013, 96), she argues that "hundreds of thousands of years of cultural development in permanent and spontaneous group formation" still have an effect today (Geenen, 2010, 79ff., own translation). The protection afforded by the group allowed humans to specialize less and adapt to the group instead. In this anthropological socio-psychological reading, which assumes an influence of millennia-old processes of socialization, the spontaneous solidarity practices of groups in disasters could thus be expected to be the 'normal' reaction of the human species and would not require further explanation. In view of challenges associated with the current pandemic, however, another one of Geenen's thoughts on solidarity is particularly interesting. For her, the

"cultural and civilisational challenge in multicultural societies today is to rethink group boundaries in the face of a globalising world and to overcome archaic insulations that are essential for survival in the early phases of human development and to create cross-cultural forms of 'we' based on solidarity" (Geenen, 2010, 81, translation by USZ).

Similar to Turner's reflections on solidarity in in- and out-groups, this idea provides a further argument for not overestimating global and transnational solidarity practices in the pandemic. Instead, we can assume that identity constructions and group boundaries play 
an important role in exclusive solidarities. Although identity constructions and group membership in general are crucial for most concepts of solidarity, there are some indications for specific group affiliations in disasters. The sequence model of disasters that I will present below vividly shows how identity constructions like 'being a full victim', which are disputed along group boundaries, can have an enormous influence on solidarity practices. To the first insight gained in this paper that solidarity practices depend on the temporal development of a disaster, I would like to add another relevant perspective at this point. Susanna Hoffman's (2020a, 2020b) model of cultural response to disaster comprises different phases of a disaster that are characterized by very different behaviours among those affected. In her model, a very short phase of "extreme individuation" (Hoffman, 2020a, 143 ) is followed by an initial phase of solidary group formation (ibid, 144ff.), which is characterized by prosocial supportive behaviour among the affected individuals and overcomes all previous differences. Of particular interest, however, is the later shift from solidarity to processes of de-solidarization (ibid, 150f.). In this phase of conflict, group affiliations are renegotiated and redefine who is considered a full victim of the disaster and who is not. In addition, the groups set themselves apart and are set apart from the outside world. At the same time opponents are sought. "The perceived foe is generally whatever agency brings or embodies, and consequently controls, restricts, or denies, restitution. Most commonly [...] it is the government" (ibid, 149). It is only during an even later phase of recovery that one observes a "dissolution of survivor unity" (ibid, 153) and the "victims to one degree or another reintegrate with the whole society" (ibid.). Turner, too, assumes that a phase of increasing solidarity is followed by a phase of bitter conflict, characterized by the search for scapegoats and the emergence of old factionalisms and widely manifested hostility (Turner, 1967, 61). This leads to my last hypothesis on individual solidarity practices. One can expect a solidarity phase of Vergemeinschaftung to be followed by a conflict phase during the disaster process. This phase will end only if and once the pandemic-specific groups disintegrate again and integrate into society as a whole. Disasterspecific solidarity practices at the micro level can thus be ended by processes of Vergesellschaftung.

In principle, the hypotheses on individual solidarity practices outlined above also apply to the meso level. Disaster-specific emergent groups, which over time become institutionalized as civil-society organizations, can sustain the conflict far beyond the actual disaster. An example would be the self-help groups in Hoffman's case study, which not only fought the insurance companies in the wake of the disaster that they themselves experienced, the Oakland firestorm, but also advised victims of other disasters years later in their struggle against their insurance companies. This shows very well that the institutionalization of formerly private solidarity practices can take decades and should be understood as a continuum of sedimentation. It can take even longer for private practices to proceed through various intermediate public stages to finally reach the level of the welfare state (see, for example, Börner, 2013, on health insurance). This makes the current rapid changes in state solidarity actions during COVID-19 even more difficult to explain-a task to which we will now turn.

\subsection{Institutional solidarity: Meso and state macro levels}

As described in the introduction, a society's institutional framework limits or enables practices of solidarity during a pandemic. In contrast to Wolf Dombrowsky who assumes that institutional solidarity cannot be disaster-specific solidarity, I believe that this depends very much on which parts of the institutional order are restricted in their functioning depending on the scenario. This may vary greatly depending on the location and structural conditions of a specific disaster. 
In general, institutional solidarity in the welfare states of the Western world varies in terms of how it is organized, which depends on historical developments and path dependencies (Esping-Andersen, 1990). These differences notwithstanding, we have witnessed an extremely rapid deployment of similar institutional forms of solidarity in response to the pandemic in a range of different countries throughout the world. In the following, I will take a systematizing look at typical pandemic responses by drawing on a few selective examples from Germany. These examples serve the purpose of illustration and could be easily supplemented or replaced by similar examples from other countries.

If we look at current responses to the pandemic, we can observe institutional solidarity in at least three dimensions:

1. The use of proven solidarity tools such as 'temporary allowances' that have been created to address such exceptional situations.

2. New institutionalizations of solidarity in which completely new measures are used that have been 'invented' especially for the pandemic. One example would be the legal 'mask obligation'.

3. Solidarity through de-institutionalization where bureaucratic processes are simplified or immediately suspended. Examples in Germany are the simplified application procedure for unemployment benefits (often publicly referred to as 'Corona-Hartz$\left.I^{\prime}\right)$ or the temporary suspension of tenant evictions and insolvency law.

Analogous to the above question about solidarity-based population behaviour, the interesting question about this extremely accelerated institutional change in solidarity is again why is it happening and the related question of how this change can be grasped theoretically.

Classical institutional analytical models usually draw on arguments about functionality and legitimacy from the fields of economics, pragmatism or neo-institutionalism. They are not designed to investigate this kind of extremely rapid institutional change and are therefore not sufficient to adequately explain the institutional solidarity practices during the COVID19 pandemic. All perspectives take either very short-term or very long-term changes into account, but what is needed is a model suitable for the analysis of long-term everyday life and 'normality' on the one hand and for the analysis of short-term exceptional situations on the other.

Furthermore, such a model should capture the effects of institutional solidarity measures themselves. In a dynamic catastrophic event in the form of a long-lasting pandemic, it is unclear to what extent the reactions to the catastrophe also constitute it. Sandra Pfister puts her finger on this point in her social constructivist reading of the current COVID-19 pandemic:

"While Stallings considers disaster responses to be disruption routines aimed at stabilising disrupted routines, the response to the Corona pandemic actually consists in the disruption of routines. Paradoxically, the suspension of order is considered the means of salvaging it. This is not to deem such measures as unnecessary. But if the experience of disaster actually consists in the disruption of the taken-for-granted order, then the response is a constituent element as well-at least to the same extent as the biological effects of the virus itself." (Pfister, 2020)

A systematic comparative analysis of institutional solidarity practices during COVID-19 calls for a theoretical model that can take exogenous causes of disaster such as the virus into account as well as endogenous causes such as the catalytic effects of the measures. To examine the expected shifts in private solidarity practices over time, a process model of the pandemic is indispensable. 
The macrosociological process model of catastrophes by Lars Clausen fulfils these requirements. It will be presented below as a theoretical framework to address questions concerning the relations of catastrophes and the dynamics of institutional solidarity.

\subsection{The macrosociological PERDUE model}

In line with current disaster research, Lars Clausen assumes that "all disasters are cultural" (Clausen, 1992, 183). In his perspective, there are no purely natural disasters which, as exogenous factors, lead to the collapse of societies. In reference to Wolf Dombrowsky, he adopts the formulation that "large scale disasters can be taken as full-scale 'falsifications of whole societies'" (ibid.). This means that in the case of "crass social change" (Clausen, 1994) knowledge and routines of action that are taken for granted suddenly cease to function and expectations lose their validity. In this sense, catastrophes can also have purely endogenous causes as a "normal outcome of social change" (Clausen, 1992, 182). In principle, knowledge about rare disasters is lost over time as part of the formation of everyday routines. Former dangers are no longer consciously taken into account even by experts in everyday life and in the formation of new routines of action. When disaster strikes, this leads to a conflict between experts and laypeople that is characterized by mistrust. Thus, even very slow social change over the course of centuries can lead to invisible threats to a society.

Drawing on Norbert Elias' concept of figuration (Elias, 1970, 139ff.), Clausen designed a model of catastrophe as a process with which crass social change can be analyzed in three dimensions. The model employs the two dimensions of rapidity and radicality that are also common in other disaster models and supplements them by a third dimension of rituality. A visualization of the model became known in Germany as Kieler Würfel (Kiel Cube), where the corners of the cube form the respective ends of the poles (Clausen, 1992, 187).

In the dimension of rapidity, social change can range from the poles of deceleration to acceleration on a visualized $X$-axis in a coordinate system. Social change can thus take place very quickly or very slowly. The dimension of radicality on the $\mathrm{Y}$-axis ranges from isolated social acts to very strong interdependence. Isolated changes in social acts are not very radical at the macro level of society. The more networked and comprehensive the respective process of change, the more radical it is for societies. The additional dimension on the Z-axis in the model is that of rituality. It allows statements about the kind of explanations that a society turns to in order to make sense of events. "One extreme is a highly rational, highly secular way of explaining things; the opposite extreme covers highly 'magical' explanations." (Clausen, 1992, 186)

With the help of these three dimensions, Clausen determined six possible paths that social change can take during a catastrophe. These are the stages:

(1) Peace is founded;

(2) Everyday routine;

(3) Rising class struggle;

(4) Disasters strike;

(5) Unconditional surrender of collective defence; and

(6) Evaporation of common values.

It is important to recognize that not every catastrophe has to pass through all these phases but that there can be different 'solutions' to the situation and these can be applied repeatedly (ibid, 188).

The PERDUE model allows us to systematically analyze how pandemic-induced solidarity practices take shape at the micro, meso and macro level in each case and how they change over time. The model is explicitly designed to include cultural and national characteristics 
of societies in the analysis of social change as endogenous causes of catastrophes. The coronavirus itself can also be included in considering a figuration as a rarely occurring external factor that affects a society with a certain degree of vulnerability.

In the following, I will use this process model to examine the German case of the current COVID-19 pandemic. In principle, the coronavirus pandemic could be analyzed globally as well as in a comparative manner. For a comparative approach between nation states, the respective expert-layperson conflict could be particularly revealing in the analysis and lends itself to further research.

\section{COVID-19 and the German case}

Since a complete systematic analysis of the German COVID-19 case is not possible in the context of this paper, the theoretical model presented here will be illustrated selectively by providing anecdotal examples from current public discourse in Germany. A comprehensive analysis to empirically test the hypotheses put forward here and the practical applicability of the model must be left to a future paper. Accordingly, the following remarks are intended to indicate what issues a fruitful future project might address.

If one approaches the current situation from a historical perspective, Germany experienced the last comparable pandemic when the Spanish flu hit in several waves of infections in 1918-1920. It, too, was a truly global pandemic that attracted comparable attention. "Since 1918, at least six other pandemics have affected public health, including three caused by influenza viruses, the HIV/AIDS pandemic, SARS and now Covid-19." (IPBES, $2020,16)$. Even back then, one could observe social practices such as wearing a face mask or regional 'flu vaccinations' at schools to protect oneself from the virus. The end of the last pandemic and the increasing medical achievements in the fight against other infectious diseases, such as vaccinations and other measures, led to a solution to the general problem of 'pandemics' and the entry of the first stage in the process model: peace is founded. This was followed by a phase of social change lasting over a hundred years, in which social practices in dealing with infectious diseases were partly forgotten by the population as well as by the responsible elites such as politicians, physicians and epidemiologists. In this second stage, everyday routines emerged that no longer took into account potential protection against infection because it no longer seemed necessary. Examples of such changed everyday practices would be the use of large-capacity carriages in trains as opposed to earlier compartments or, more generally, the use of air conditioning instead of opening windows in vehicles and buildings. As these inventions were introduced, simply no one thought that these practices posed new dangers. These are typical unintended side effects. These examples of hidden reasons are further purely endogenous factors that have increased the vulnerability of German society to disasters and catastrophes stemming from epidemics and pandemics. It goes without saying that medical knowledge in microbiology and neighbouring fields is more advanced today than one hundred years ago. Yet knowledge about the effectiveness of everyday practices such as self-stitched face masks was still extremely controversial among experts at the beginning of the current pandemic. And just as there were early advocates, there were also sceptics in the ranks of politics and science from the outset who strongly doubted the effectiveness of the masks. Even in the dimension of rituality, completely irrational rumours and fears quickly gained currency that - similar to the anti-vaccination debate-attributed harmful effects to the masks, including the death of children. Ultimately, it took until the end of April 2020 before masks became mandatory in Germany.

The third stage, which according to Clausen is characterized by growing class conflict, can be described very clearly in Germany by reference to the homeopathy controversy. Even before the COVID-19 pandemic, there was mistrust in what some call 'orthodox medicine'. Alternative methods of treating diseases are very popular among large parts of the 
population, and even the public health-insurance providers partly cover the costs of homeopathic treatment, the effectiveness and coverage of which is highly controversial. In the dimension of rituality this would be an example of a current conflict between explanations bordering on the 'magical' and the 'rational' ones favoured by the health-care system. The neoliberal reforms of the German health-care system in recent years, which introduced profit orientation in hospitals, for example, can be interpreted as endogenous causes of rising class struggles in the German health-care system. In this context, it would seem logical to examine the differences between privately and state-insured persons, a distinction that is colloquially referred to as Zwei-Klassen-Medizin (the implication being that this involves a first- and a second-class medical treatment).

The fourth stage is the striking of the current disaster and coincides with the first COVID19 cases in Bavaria at the end of January 2020. It continues still today. The reactions of the population and the measures taken by the government can be interpreted as acute collective defence. So far there has been no fifth stage of collective 'surrender' and therefore no sixth stage of an evaporation of common values.

Quite to the contrary, I would like to argue that 'solidarity' in stage four still serves as the central shared normative value for the figuration of the German COVID-19 case. Both experts and laypeople employ the concept of solidarity as a strategy of legitimation. Social distancing and the wearing of face masks are considered acts of solidarity towards risk groups. Solidarity practices from below, like self-organized childcare or the increased activities of already existing or spontaneously emerging civil-society groups, are labelled as local solidarity. Even though the pandemic may affect people to different degrees, it is first and foremost perceived as an event that has come upon all citizens as one large group. Financial economic aid and the use of proven solidarity tools such as temporary allowances are framed as solidarity with the economically affected. Interestingly, however, they are also more likely to be affected by the consequences of government countermeasures than by the virus itself. At this point, the relevance of considering endogenous causes and not only the virus as an external factor once again becomes particularly clear. Even if the appropriateness of such solidarity with, for example, the Lufthansa airline immediately raised public doubts, the notion of solidarity nevertheless constitutes a value shared by both the advocates and opponents of extending support to the airline. The temporary suspension of eviction or insolvency laws are two other examples of governmental solidarization with those affected by the pandemic, in this case by means of de-institutionalization as explained above.

If we recall the theoretical insights and propositions about time and group boundaries described in the first part of this paper, there is reason to assume that Germany might still be awaiting a conflict-laden phase in which the practices of solidarity will reach their limits and there will be a shift toward de-solidarization. In Clausen's model, such a phase can be expected to occur only in the fifth stage, when the shared normative basis erodes. The thesis proposed here is that the concept of solidarity fulfils a dual function in preventing German society from drifting into this phase. On the one hand, it serves as a culturally guiding value in processes of Vergemeinschaftung and promotes the formation of groups and identities from below. On the other hand, it is part of the normative basis of a community for processes of Vergesellschaftung from above. This reciprocal influence has a stabilizing effect on remaining in the fourth stage of the catastrophe.

Whatever the case may be, the structure of the disaster as a long-lasting pandemic, in which even the development of a vaccine cannot rapidly pacify the situation and return life to stage 1, can be expected to induce an increasing loss of confidence and mistrust in experts and the government during the next period of the pandemic. Moreover, the above considerations about a long-term increase in the attractiveness of non-technical strategies of addressing catastrophes (3.1) could be supplemented with the dimension of rituality in 
Clausen's model. In addition to the assumption that social practices could play an enhanced role in political strategies, the idea of a general increase in practices that are not just rational could be added. In this regard, alternative ideas both of a religious and magical kind could be considered in a future analysis. A systematic analysis of the solidarity practices in the current pandemic would have to include the theoretical considerations and propositions put forward so far as well as to examine more closely how the interrelationships of the German figuration present themselves. This would appear to be a useful undertaking for disaster and solidarity research in the future.

\section{Conclusion}

In this article, I have proposed a theoretical framework to conceptualize the changes in solidarity practices induced by the current pandemic. The proposal involved assumptions about both private solidarity practices at an individual level and governmental solidarity practices at an institutional level. Drawing on findings from disaster research, I identified time as a key category for a systematic analysis of solidarity practices in the COVID-19 pandemic. In addition to duration and sequence as elements of a disaster that need to be considered, speed emerged as another influential factor on solidarity. The empirical findings of previous research, corroborated over decades, suggest that we can expect prosocial behaviour in disasters. This observation proved to be particularly relevant to the considerations on individual solidarity practices and their potential change over time. Apart from the insight that the analysis of solidarity in disasters requires a process model, the main result of the theoretical reflections on changes in institutional solidarity was that understanding solidarity in disasters requires considering endogenous and exogenous factors. Since Lars Clausen's macrosociological process model (PERDUE) meets all these requirements, its analytical potential was discussed using anecdotal evidence from a case study on the COVID-19 pandemic in Germany. The discussion showed that this model can be used to carry out a figurative analysis that takes a comparative look at the current solidarity practices in the pandemic. Whether the model can prove its worth in practice and what problems might emerge when a systematic analysis is performed in detail is an open question that will have to be answered in the future. A combination of the theoretical approach presented here with a comprehensive discourse analysis of the expert-layperson conflict on COVID-19 would seem interesting and promising in any case.

\section{References}

Alexander, D. (2020). COVID-19 and the disaster research 'gold rush'. Alert-Journal of the Institute of Civil Protection and Emergency Management. Covid-19 extended edition. Summer 2020, 34-35.

Barkun, M. (1977). Disaster in history. Mass Emergencies, 2, 219-231.

Bayertz, K. (1998). Begriff und Problem der Solidarität. In K. Bayertz (Ed.), Solidarität. Begriff und Problem (11-53). Frankfurt a. M.: Suhrkamp.

Borck, C. (2020). Soziologisches zur Pandemie VI: Eine Sammlung aktueller Wortmeldungen. Soziopolis. Retrieved from: https://soziopolis.de/lesen/presse/artikel/soziologischeszur-pandemie-vi/. Accessed 5 October 2020.

Börner, S. (2013). Belonging, Solidarity and Expansion in Social Policy. Basingstoke: Palgrave Macmillan. 
Börner, S. (2018). Strittige Solidarität. Zur Elastizität von Solidaritätskonstruktionen in den deutschen und britischen Arbeiterunterstützungskassen des 19. Jahrhunderts. Zeitschrift für Sozialreform, 64(1), 23-49.

Carr, L.J. (1932). Disaster and the Sequence-Pattern Concept of Social Change. American Journal of Sociology, 38(2), 207-218.

Claessens, D. (2013). Instinkt, Psyche, Geltung: Bestimmungsfaktoren menschlichen Handelns. Köln, Opladen: Westdeutscher Verlag.

Clausen, L., \& Dombrowsky W.R. (1983). Einführung in die Soziologie der Katastrophen. Bundesamt für Zivilschutz (Ed.) Zivilschutzforschung, Schriftenreihe der Schutzkommission beim Bundesministerium des Innern, Band 14. Bonn: Osang.

Clausen, L. (1992). Social Differentiation and the Long-Term Origin of Disasters. Natural Hazards, 6, 181-190.

Clausen, L. (1994). Krasser sozialer Wandel. Opladen: Leske + Budrich.

Clausen, L., Geenen, E. M. \& Elísio, M. (Eds.) (2003). Entsetzliche soziale Prozesse. Theorie und Empirie der Katastrophen. Münster: LIT Verlag.

Critical Inquiry (2020). Posts from the pandemic. Retrieved from: https://criticalinquiry.uchicago.edu/posts_from_the_pandemic/ Accessed 5 October 2020.

Dallinger, U. (2009). Die Solidarität der modernen Gesellschaft. Der Diskurs um rationale oder normative Ordnung in Sozialtheorie und Soziologie des Wohlfahrtsstaats. Wiesbaden: VS Verlag.

DG ECHO (2020). \#StrongerTogether: the EU's Civil Protection response to Coronavirus. Retrieved from: https://ec.europa.eu/echo/field-blogs/photos/strongertogether-eu-scivil-protection-response-coronavirus_en. Accessed 5 October 2020.

Dombrowsky, W. R. (1981). Solidaritätsformen während der Schneekatastrophen in Norddeutschland. SIFKU-Informationen (44), 27-38.

Dombrowsky, W. R. (1998). Again and again. Is a disaster what we call a sdisasterı? In E. L. Quarantelli (Ed.), What is a Disaster? Perspectives on the Question (19-30). London: Routledge.

Dombrowsky, W.R. (1983). Soziologische Katastrophenforschung im Aufriß. In L. Clausen \& W.R. Dombrowsky (Eds.), Einführung in die Soziologie der Katastrophen. Bundesamt für Zivilschutz (Ed.) Zivilschutzforschung, Schriftenreihe der Schutzkommission beim Bundesministerium des Innern, Band 14 (11-39). Bonn: Osang.

Dombrowsky, W.R. (1995). Zum Teufel mit dem Bindestrich. Zur Begründung der Katastrophen(-)Soziologie in Deutschland durch Lars Clausen. In W.R. Dombrowsky \& U. Pasero (Eds.), Wissenschaft, Literatur, Katastrophe. Festschrift zum sechzigsten Geburtstag von Lars Clausen (108-122). Opladen: Westdeutscher Verlag. 
Dombrowsky, W.R. (2008). Zur Entstehung der soziologischen Katastrophenforschung. Eine wissenshistorische und -soziologische Reflexion. In C. Felgentreff \& T. Glade (Eds.), Naturrisiken und Sozialkatastrophen (63-76). Berlin; Heidelberg: Spektrum Akademischer Verlag.

Dombrowsky, W.R. (2010). Entstehung und Ansätze der Katastrophensoziologie. In A. Siedschlag (Ed.), Jahrbuch für europäische Sicherheitspolitik 2009/2010 (51-67). Baden-Baden: Nomos.

Durkheim, E. (1964). The Division of Labor in Society. [1893], New York: Free Press.

DW (2020, October 25). Spain declares new coronavirus state of emergency. Retrieved from: https://p.dw.com/p/3kPmL. Accessed 29 March 2021.

Elias, N. (1970). Was ist Soziologie? In D. Claessens (Ed.), Grundfragen der Soziologie. Band 1. Munich: Juventa Verlag.

Erlanger, S. (2020, March 16). Macron Declares France 'at War' With Virus, as E.U. Proposes 30-Day Travel Ban. Retrieved from: https://www.nytimes.com/2020/03/16/ world/europe/coronavirus-france-macron-travel-ban.html. Accessed 5 October 2020.

Esping-Andersen, G. (1990). The Three Worlds of Welfare Capitalism. Princeton: Princeton University Press.

Geenen, E. M. (2003). Kollektive Krisen: Katastrophe, Terror, Revolution - Gemeinsamkeiten und Unterschiede. In L. Clausen, E.M. Geenen \& M. Elísio (Eds.), Entsetzliche soziale Prozesse. Theorie und Empirie der Katastrophen (5-23). Münster: LIT Verlag.

Geenen, E. M. (2010). Bevölkerungsverhalten und Möglichkeiten des Krisenmanagements und Katastrophenmanagements in multikulturellen Gesellschaften. Bundesamt für Bevölkerungsschutz und Katastrophenhilfe (Ed.), Forschung im Bevölkerungsschutz, 11. Bonn: Osang.

Hoffman, S. M. (2020a). "The worst of times, the best of times": Toward a model of cultural response to disaster. In A. Oliver-Smith \& S.M. Hoffman (Eds.). The Angry Earth. Disaster in Anthropological Perspective (141-157). Second edition. London, New York: Routledge.

Hoffman, S. M. (2020b). Postscript: Behind the stages and act four: More of the worst of times, the best of times model. In A. Oliver-Smith \& S. M. Hoffman (Eds.). The Angry Earth. Disaster in Anthropological Perspective (157-161). Second edition. London, New York: Routledge.

Holenstein, M. \& Köng, A. L. (2014). Das Verhalten der Bevölkerung in Katastrophen und Notlagen. Schlussbericht der Literaturstudie, Stiftung Risiko-Dialog St. Gallen.

Hondrich, K. O. \& Koch-Arzberger, C. (1992). Solidarität in der modernen Gesellschaft. Frankfurt a.M.: Fischer.

IPBES (2020). Workshop report on biodiversity and pandemics of the Intergovernmental Platform on Biodiversity and Ecosystem Services. Daszak, P., das Neves, C., Amuasi, J., Hayman, D., Kuiken, T., Roche, B., Zambrana-Torrelio, C., Buss, P., Dundarova, H., Feferholtz, 
Y., Foldvari, G., Igbinosa, E., Junglen, S., Liu, Q., Suzan, G., Uhart, M., Wannous, C., Woolaston, K., Mosig Reidl, P., O'Brien, K., Pascual, U., Stoett, P., Li, H., Ngo, H. T., IPBES secretariat. Bonn, Germany. DOI:10.5281/zenodo.4147318.

Kaufmann, F. X. (2013). Variations of the Welfare State: Great Britain, Sweden, France and Germany between Capitalism and Socialism. Berlin: Springer.

Lorenz, D.F. (2010). Kritische Infrastrukturen aus Sicht der Bevölkerung. Schriftenreihe Sicherheit, Forschungsforum Öffentliche Sicherheit der FU Berlin. Retrieved from: https://www.sicherheit-forschung.de/forschungsforum/schriftenreihe_neu/3/index.html.

Lorenz, D.F. \& Dittmer, C. (2020). (Disaster) utopian moments in the pandemic: A European perspective. items. Insights from the Social Sciences. Social Science Research Council. Retrieved from: https://items.ssrc.org/covid-19-and-the-social-sciences/disaster-studies/disaster-utopian-moments-in-the-pandemic-a-european-perspective/.

Montano, S. \& Savitt, A. (2020). Not all disasters are disasters: Pandemic categorization and its consequences. items. Insights from the Social Sciences. Social Science Research Council. Retrieved from: https://items.ssrc.org/covid-19-and-the-social-sciences/disasterstudies/not-all-disasters-are-disasters-pandemic-categorization-and-its-consequences/.

Oliver-Smith, A. \& Hoffman, S. M. (Eds.) (2020). The Angry Earth. Disaster in Anthropological Perspective. Second edition. London, New York: Routledge.

Oliver-Smith, A. (2020). "What is a disaster?": Anthropological Perspectives on a Persistent Question, Postscript. In A. Oliver-Smith \& S. Hoffman (Eds.), The Angry Earth. Disaster in Anthropological Perspective (29-44). Second edition. London, New York: Routledge.

Perry, R.W. \& Quarantelli, E.L. (Eds.) (2005). What is a Disaster? New Answers to Old Questions. Philadelphia: Xlibris.

Pfister, S. (2020). The Social Definition of the Corona Pandemic. The European Sociologist, Special Issue: Pandemic (Im)Possibilities, 45(1). Retrieved from: https://www.europeansociologist.org/issue-45-pandemic-impossibilities-vol-1/theorising-\%E2\%80\%93-social-definition-corona-pandemic.

Pitzke, M. (2020, March 26). New York City wird zum Epizentrum der Coronakrise. Retrieved from: https://www.spiegel.de/politik/ausland/coronakrise-new-york-city-wirdzum-epizentrum-a-2f0391f6-386a-4d1c-bdb1-9e55633bf8ef. Accessed 29 March 2021.

Prainsack, B. (2020). Solidarity in pandemics. Democratic Theory, 7(2), Winter 2020, 124133. Retrieved from: https://doi.org/10.3167/dt.2020.070215.

Prince, S. (1920). Catastrophe and Social Change: Based Upon a Sociological Study of the Halifax Disaster. New York.

Prisching, M. (2003). Solidarität. Der vielschichtige Kitt gesellschaftlichen Zusammenlebens. In S. Lessenich (Ed.), Wohlfahrtsstaatliche Grundbegriffe (167-173). Frankfurt a.M.: Campus. 
Prisching, M. (2005). Good Bye New Orleans. Der Hurrikan Katrina und die amerikanische Gesellschaft. Graz: Leykam.

Quarantelli, E. L. (2003). Auf Desaster bezogenes soziales Verhalten. Eine Zusammenfassung der Forschungsbefunde von fünfzig Jahren. In L. Clausen, E. M. Geenen \& M. Elísio (Eds.), Entsetzliche soziale Prozesse. Theorie und Empirie der Katastrophen (25-33). Münster: LIT Verlag.

Quarantelli, E.L. \& Dynes, R. (1977). Response to social crisis and disaster. Annual Review of Sociology, 3, 23-49.

Quarantelli, E.L. (Ed.) (1998). What is a Disaster? Perspectives on the Question. London: Routledge.

Riegert, B. (2021, March 18). Ein Jahr nach dem Corona-Drama von Bergamo: Die müden Helden. Retrieved from: https://p.dw.com/p/3qVQQ. Accessed 29 March 2021.

Scanlon, T. (1988). Disasters little known pioneer: Canada's Samuel Henry Prince. International Journal of Mass Emergencies and Disasters, 6(3), 213-232.

Stehrenberger, C. S. (2020). Disaster studies as politics with other means: Covid19 and the legacies of cold war disaster research. items. Insights from the Social Sciences. Social Science Research Council. Retrieved from: https://items.ssrc.org/covid-19-and-thesocial-sciences/disaster-studies/disaster-studies-as-politics-with-other-means-covid-19and-the-legacies-of-cold-war-disaster-research/.

Tierney, K. (2020). Pandemic and Disaster: Insights from Seventy Years of Social Science Disaster Research. items. Insights from the Social Sciences. Social Science Research Council. Retrieved from: https://items.ssrc.org/covid-19-and-the-social-sciences/disaster-studies/pandemic-and-disaster-insights-from-seventy-years-of-social-science-disaster-research/.

Tönnies, F. (1887). Gemeinschaft und Gesellschaft. Leipzig: Fues's Verlag (R. Reisland). Retrieved from: http://www.deutschestextarchiv.de/book/view/toennies_gemeinschaft_ $1887 ? \mathrm{p}=9$.

Turner, R. (1967). Types of solidarity in the reconstituting of groups. The Pacific Sociological Review, 10(2), 60-68.

Voss, M. (2006). Symbolische Formen: Grundlagen und Elemente einer Soziologie der Katastrophe. Bielefeld: transcript Verlag.

Wikipedia (2020). COVID-19 Pandemic by country and territory. Retrieved from: https://en.wikipedia.org/wiki/COVID-19_pandemic_by_country_and_territory\#Europe Accessed 06 November 2020.

WHO (2020). Timeline of WHO's response to COVID-19. Retrieved from: https:// www.who.int/emergencies/diseases/novel-coronavirus-2019/interactive-timeline\#. Accessed 5 October 2020. 
ZSKG (2020). Gesetz über den Zivilschutz und die Katastrophenhilfe des Bundes (Zivilschutz- und Katastrophenhilfegesetz - ZSKG). 